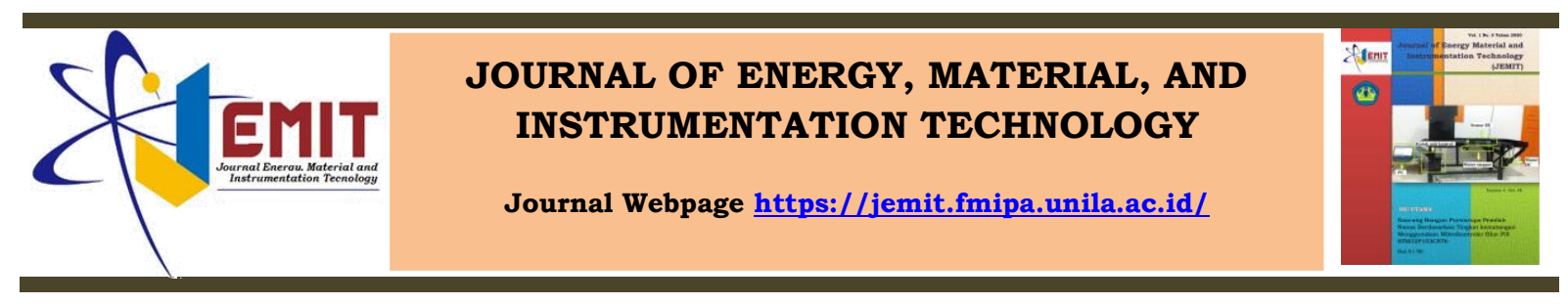

\title{
Rancang Bangun Sistem Monitoring Kualitas Air Tambak Udang (Litopenaeus Vannamei) Menggunakan Wireless Sensor Sistem (WSS) yang Terintegrasi dengan PLC CPM1A
}

\author{
Gurum Ahmad Pauzi ${ }^{*}$, Okta Ferli Suryadi ${ }^{1}$, Gregorius Nugroho Susanto ${ }^{2}$, dan Junaidi ${ }^{1}$
}

1. Jurusan Fisika, Universitas Lampung, Bandar Lampung, Indonesia, 35141

2. Jurusan Biologi, Universitas Lampung, Bandar Lampung, Indonesia, 35141

\begin{tabular}{|c|c|}
\hline Article Information & Abstract \\
\hline $\begin{array}{l}\text { Article history: } \\
\text { Received June } 11^{\text {th }}, 2020 \\
\text { Received in revised form } \\
\text { June } 15^{\text {th }}, 2020 \\
\text { Accepted June } 16^{\text {th }}, 2020 \\
\text { Keywords: } \\
\text { Arduino UNO, Monitoring } \\
\text { System, Water Quality, } \\
\text { Litopenaeus Vannamei }\end{array}$ & $\begin{array}{l}\text { The research about } p H \text {, salinity, dissolved oxygen, and temperature monitoring } \\
\text { system using Arduino Uno integrated with PLC CPM1A for water quality control of } \\
\text { shrimp farm litopenaeus vannamei had done. The system used } p H \text { meter kit Dfrobot } \\
\text { sensor, salinity sensor, DS } 18 B 20 \text { waterproof sensor, and analog dissolved oxygen } \\
\text { sensor which was controlled by Arduino UNO. In order to calibrate the sensor, pH } \\
\text { meter kit Dfrobot sensor was calibrated by using a buffer solution, salinity sensor } \\
\text { was calibrated by refractometer, DS18B2O waterproof sensor was calibrated by } \\
\text { HTC-O2 thermometer, and an analog dissolved oxygen sensor was calibrated by DO } \\
\text { meter YSI 55. The results showed that the sensors can detect pH, salinity, dissolved } \\
\text { oxygen and temperature with accuracy } 94.06 \%, 78.15 \%, 90.53 \% \text { and } 99.42 \% \\
\text { respectively. It is transmitted wireless by using the nRF } 24101+\text { module. The furthest } \\
\text { distance in the line of sigh test was } 405 \text { meters and in non-line of sigh was } 163 \\
\text { meters. The measurement had done } 3 \text { times per day (morning, afternoon, evening) in } \\
3 \text { days. The relay also can be integrated with PLC CPM1A to control the wheel and } \\
\text { water pump. }\end{array}$ \\
\hline
\end{tabular}

\begin{tabular}{|c|c|}
\hline Informasi Artikel & Abstrak \\
\hline $\begin{array}{l}\text { Proses artikel: } \\
\text { Diterima } 11 \text { Juni } 2020 \\
\text { Diterima dan direvisi dari } \\
15 \text { Juni } 2020 \\
\text { Accepted } 16 \text { Juni } 2020 \\
\text { Kata kunci: } \\
\text { Arduino UNO, Sistem } \\
\text { Monitoring, Kualitas Air, } \\
\text { Litopenaeus Vannamei }\end{array}$ & $\begin{array}{l}\text { Telah direalisasikan sebuah sistem yang mampu memonitoring pH, salinitas, } \\
\text { dissolved oxygen, dan temperatur berbasis arduino yang terintegrasi dengan PLC } \\
C P M 1 A \text { untuk pengendalian kualitas air tambak udang. Sistem ini menggunakan } \\
\text { sensor pH meter kit Dfrobot, sensor salinitas, sensor DS18B2O waterproof dan } \\
\text { sensor analog dissolved oxygen yang dikendalikan oleh mikrokontroler Arduino } \\
\text { UNO. Mekanisme pengujian sensor dilakukan dengan cara membandingkan } \\
\text { pembacaan sensor dengan alat yang terkalibrasi. Pengujian sensor pH meter kit } \\
\text { Dfrobot dilakukan dengan menggunakan larutan buffer, sensor salinitas dengan } \\
\text { refractometer, sensor DS18B2O waterproof dengan thermometer HTC-O2, dan sensor } \\
\text { analog dissolved oxygen dengan DO meter YSI } 55 \text {. Hasil penelitian menunjukkan } \\
\text { sensor pada sistem ini mampu mendeteksi nilai pH, salinitas, dissolved oxygen dan } \\
\text { temperature dengan akurasi masing-masing parameter } 94,06 \% \text {, } 78,15 \% \text {, } 90,53 \% \\
\text { dan } 99,42 \% \text {. Data dikirimkan secara wireless menggunakan modul nRF } 24101+\text {. } \\
\text { Jarak pengiriman terjauh pada pengujian tanpa penghalang (line of sigh) diperoleh } \\
\text { sebesar } 405 \text { meter dan pada pengujian dengan adanya penghalang (non line of } \\
\text { sigh) diperoleh sebesar } 163 \text { meter. Pengujian keseluruhan sistem dilakukan selama } \\
3 \text { hari sebanyak } 3 \text { kali pengukuran perhari (pagi, siang, sore). Sistem pengendalian } \\
\text { relay dapat terintegrasi dengan PLC CPM1A untuk pengendalian kincir dan pompa } \\
\text { air. }\end{array}$ \\
\hline
\end{tabular}

\section{Pendahuluan}

Indonesia sebagai Negara kepulauan memiliki potensi dibidang perikanan dengan budidaya udang sebagai komoditas ekspor unggulan. Udang jenis Vaname (Litopenaeus vannamei) merupakan salah satu komoditi perikanan yang dibudidayakan di Indonesia. Udang ini mulai masuk dan dikenalkan di Indonesia pada tahun 2001 melalui SK Menteri Kelautan dan Perikanan RI. No. 41/2001 sebagai upaya untuk meningkatkan produksi

* Corresponding author.

E-mail addres: gurum@fmipa.unila.ac.id 
udang Indonesia menggantikan udang windu (Penaeus monodon) yang telah mengalami penurunan. Beberapa keunggulan yang dimiliki udang putih antara lain responsive terhadap pakan yang diberikan, lebih tahan terhadap penyakit dan lingkungan yang kurang baik (Pratama, 2017).

Keberhasilan dalam budidaya udang vaname dapat dipengaruhi oleh beberapa faktor, salah satunya adalah kualitas air. Kualitas air tambak merupakan faktor yang sangat penting untuk keberlangsungan hidup dan produktivitas budidaya udang (Fuady, 2013). Kualitas air tambak yang baik, dapat dilihat dari parameter fisika seperti temperatur, oksigen terlarut (DO), derajat keasaman $(\mathrm{pH})$, kadar garam (salinitas) dan ketinggian air (Hudi dan Shahab, 2005). Kreteria kualitas air tambak udang dalam keadaan standar meliputi: pH sekitar 7-8, salintas 5-40 ppt, ketinggian air 80-120 cm, temperature air $26^{\circ} \mathrm{C}-30^{\circ} \mathrm{C}$, kecerahan air $25-45 \mathrm{~cm}$, dan konsentrasi oksigen terlarut/ Dissolved Oxygen (DO) ideal untuk pertumbuhan udang adalah 4,5 mg/L hingga $7 \mathrm{mg} / \mathrm{L}$ (Komarawidjaja, 2006). Buruknya kualitas air dapat menyebabkan menurunnya nafsu makan udang, penggemukan udang menjadi lambat, dan mudah terserang penyakit (Arsad, 2017). Untuk menghindari masalah-masalah tersebut maka perlu dilakukan monitoring dan kontrol kualitas air tambak sehingga kualitas air dapat terkendali dengan baik.

Sistem monitoring adalah sebuah kegiatan yang mencakup pengumpulan, peninjauan ulang dan tindakan atas sesuatu proses yang berjalan pada sebuah sistem. Pada dasarnya pemantauan untuk memastikan sebuah sistem dapat berjalan sesuai dengan keadaan yang telah ditetapkan atau tidak. Dengan pemantauan diharapkan sebuah sistem dapat menghasilkan keluran monitoring berupa peningkatan kualitas yang terjadi terhadap suatu objek yang dipantau.

Beberapa alat monitoring kualitas air telah dikembangkan di Indonesia seperti sistem monitoring kualitas air pada kolam ikan berbasis wireless sensor network menggunakan komunikasi zigbee (lintang dkk., 2017), sistem monitoring kualitas air tambak udang Vaname yang dapat memberikan informasi melalui Short Massage System (SMS) (Multazam dan Hasanuddin, 2017), dan sistem monitoring kualitas air pada budidaya tambak udang dan bandeng (Machzar dkk., 2018). Berdasarkan sistem yang banyak dikembangkan di Indonesia hanya terdiri dari 2 sampai 3 parameter penting yang terpasang pada sistem monitoring. Sedangkan pada kualitas air pada tambak udang terdiri dari 4 parameter penting yaitu temperatur, $\mathrm{pH}$, salinitas dan $\mathrm{DO}$.

Dari uraian diatas, kami mencoba mengembangan sistem monitoring kualitas air tambak udang dengan menambahkan parameter pengukuran diantaranya $\mathrm{pH}$, salinitas, DO dan temperatur sehingga dapat memberikan informasi kualitas air yang lebih baik untuk proses monitoring. Alat yang dirancang akan menggunakan sistem nirkabel yang mampu melakukan pengukuran dengan jarak yang cukup jauh menggunakan gelombang radio nRF24101+ secara real time. Alat monitoring kualitas air tambak ini menggunakan Arduino UNO untuk mengolah data pengukuran sensor dan akan memanfaatkan LCD 20x4 untuk menampilkan data sensor. Pada sistem yang akan dipasang kendali otomatis kincir air dan pompa untuk menjaga kualitas air tambak.

\section{Metode Penelitian}

\subsection{Perancangan Hardware}

Perancangan perangkat keras (hardware) merupakan tahap penyusunan komponen-komponen elektronika menjadi satu kesatuan sistem agar dapat bekerja sesuai dengan yang diharapkan. Secara umum, rancangan sistem monitoring yang akan dibuat ditunjukkan dalam diagram blok pada Gambar 1.

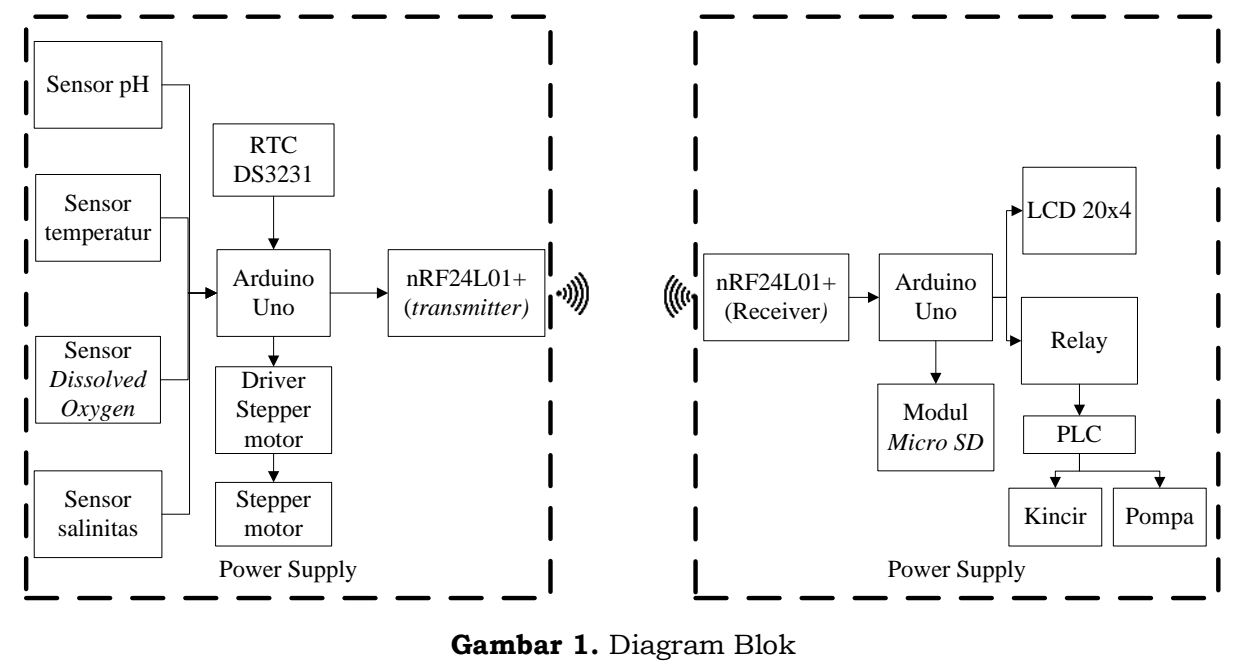

Pada Gambar 1 merupakan blok diagram perangkat keras (hardware) terbagi menjadi dua bagian yaitu blok diagram pengukuran dan blok diagram sistem proses data. Pada blok diagram pengukuran terdiri dari sensor $\mathrm{pH}$ Meter Kit, sensor temperature, sensor Analog Dissolved Oxygen, sensor salinitas, Real Time Clock (RTC) DS-3231, driver stepper motor, transceiver nRF24L01+ (transmitter), power supply. Pada blok tersebut, terdapat sensor digital temperature DS18B20 yang digunakan untuk mengukur dan mendeteksi temperature air, sensor pH V1.1 Meter Kit yang digunakan untuk mengukur dan mendeteksi kadar $\mathrm{pH}$, sensor salinitas yang digunakan untuk mengukur dan mendeteksi kadar garam, sensor Analog Dissolved Oxygen (DO) yang digunakan untuk mengukur dan mendeteksi oksigen terlarut dalam air tambak udang, dan RTC DS-3231 yang berfungsi sebagai modul 
perwaktuan pada saat proses pengambilan data. Proses pengambilan data oleh sensor dibantu oleh motor stepper yang berfungsi menurunkan dan mengangkat sensor pada saat melakukan pengukuran keempat parameter. Sensor analog pH meter kit, Analog Dissolved Oxygen, dan salinitas menghasilkan keluaran berupa data analog yang kemudian dihubungkan pada pin analog input pada Arduino Uno. Sedangkan sensor temperatur DS18B20 menghasilkan keluaran berupa data digital yang dapat langsung dibaca oleh Arduino dengan menghubungkan pin data output sensor ke pin digital input pada Arduino Uno.

Data keluaran dari keempat sensor tersebut kemudian diolah oleh Arduino. Selanjutnya output data keempat sensor dikirim menggunakan modul transceiver nRF24L01+ (transmitter) yang akan diterima oleh modul transceiver $\mathrm{nRF} 24 \mathrm{L01}+$ (receiver). Sistem pengolahan data terdapat receiver berupa modul transceiver nRF24L01+ yang berfungsi untuk menerima data dari sistem pengiriman data, selanjutnya data dibaca oleh Arduino Uno. Hasil pembacaan dari data sensor, ditampilkan melalui LCD 20x4.

\subsection{Perancangan Software}

Perancangan software pada penelitian ini digunakan aplikasi Arduino IDE. Program tersebut berisikan perintah untuk menjalankan fungsi dari rangkaian pengendali. Program pengendali berisikan tiga perintah. Perintah yang dijalankan pertama adalah melakukan perintah otomatisasi untuk mengambil data sesuai dengan waktu pengambilan data monitoring. Kemudian, perintah kedua adalah membaca data dari masing-masing parameter dengan sensor berdasarkan waktu pengukuran dari RTC (Real Time Clock) lalu data dikirim melalui transceiver nRF24L01+ (transmitter). Perintah ketiga adalah data yang diterima melalui transceiver nRF24L01+ (receiver) diolah. Kemudian data ditampilkan melalui LCD 20x4 dan juga dikirimkan melalui port serial agar dapat dibaca melalui komputer. Perancangan perangkat lunak (software) dapat dilihat pada Gambar 2.

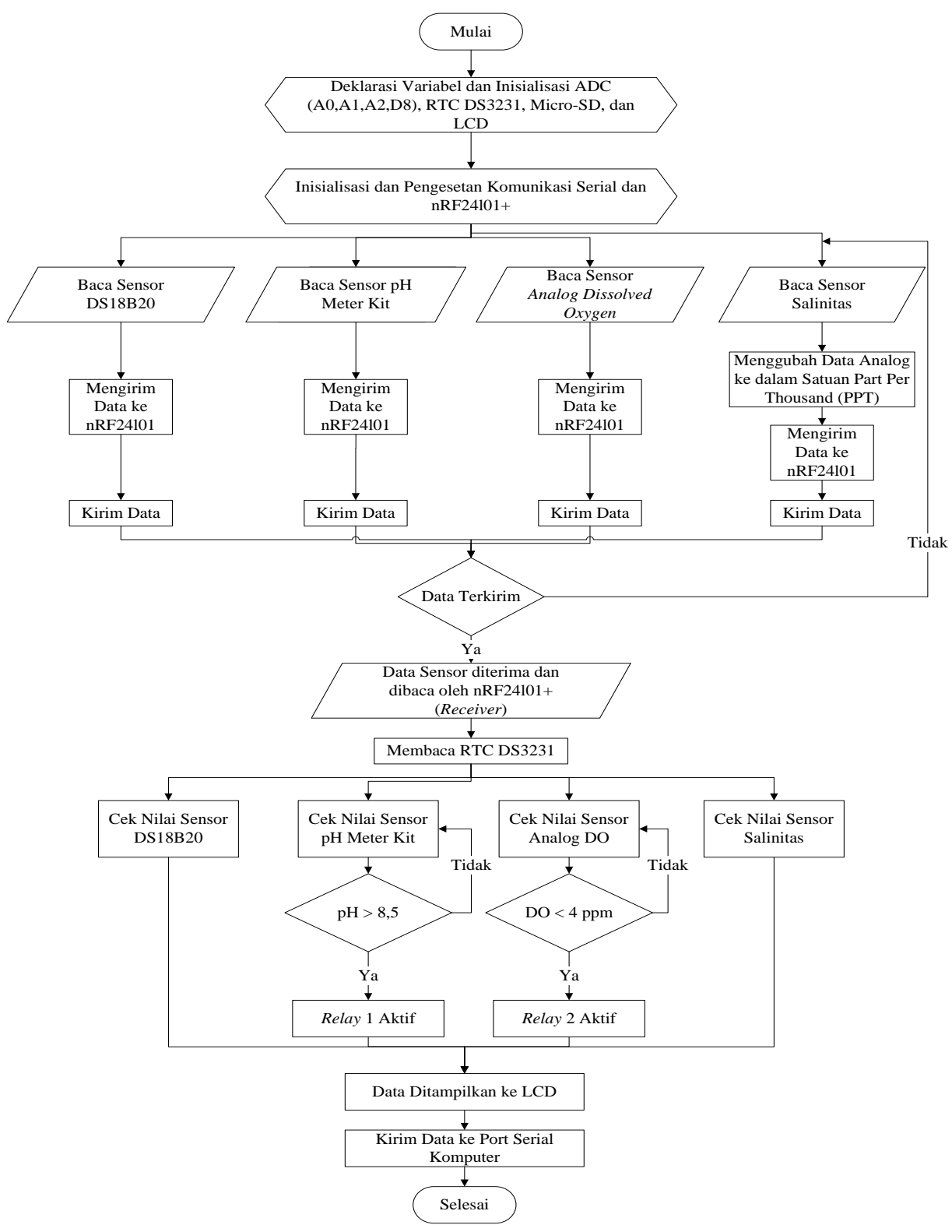

Gambar 2. Diagram Alir Perancangan Perangkat Lunak (Software) 
Pauzi GA, Suryadi OF, Susanto GN, dan Junaidi, 2020, Rancang Bangun Sistem Monitoring Kualitas Air Tambak Udang (Litopenaeus Vannamei) Menggunakan Wireless Sensor Sistem (WSS) yang Terintegrasi dengan PLC CPM1A, Jurnal of Energy, Material, and Instrumentation Technology, Vol. 1 No. 3, 2020

Data hasil pengukuran dari masing-masing sensor digunakan untuk menghitung persentase kesalahan (error), akurasi dan presisi dari masing- masing sensor. Untuk menghitung presentase kesalahan, akurasi, dan presisi menggunakan Persamaan 1-3.

$$
\begin{gathered}
\text { \%Error }=\left|\frac{Y-X_{n}}{Y}\right| \times 100 \% \\
\text { \%Akurasi }=\left(1-\left|\frac{Y-X_{n}}{Y}\right|\right) \times 100 \% \\
\text { \%Presisi }=\left(1-\left|\frac{X_{n}-\bar{X}_{n}}{\bar{X}_{n}}\right|\right) \times 100 \%
\end{gathered}
$$

dengan $Y$ adalah nilai parameter referensi, $X_{n}$ adalah nilai parameter terukur ke-n, dan $\bar{X}_{n}$ adalah rata-rata nilai parameter $n$ terukur (Jones dan Chin, 1991).

\section{Hasil dan Pembahasan}

\subsection{Perancangan Perangkat Keras/Hardware}

Sistem monitoring ini memanfaatkan jaringan nirkabel dengan menggunakankan modul nRF24L01+ sebagai media pengiriman data. Hasil realisasi perangkat keras pengirim data (transmitter) dari sistem monitoring $\mathrm{pH}$, salinitas, oksigen terlarut, dan temperatur ditunjukkan pada Gambar 3.

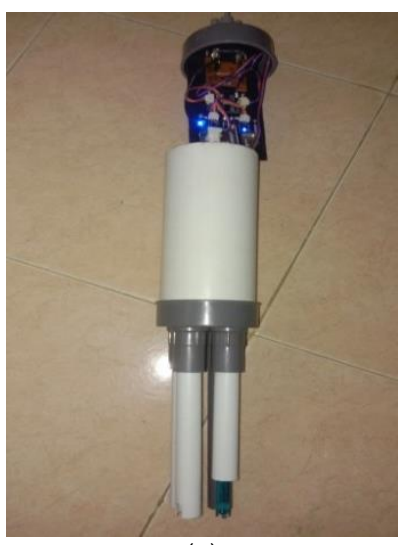

(a)

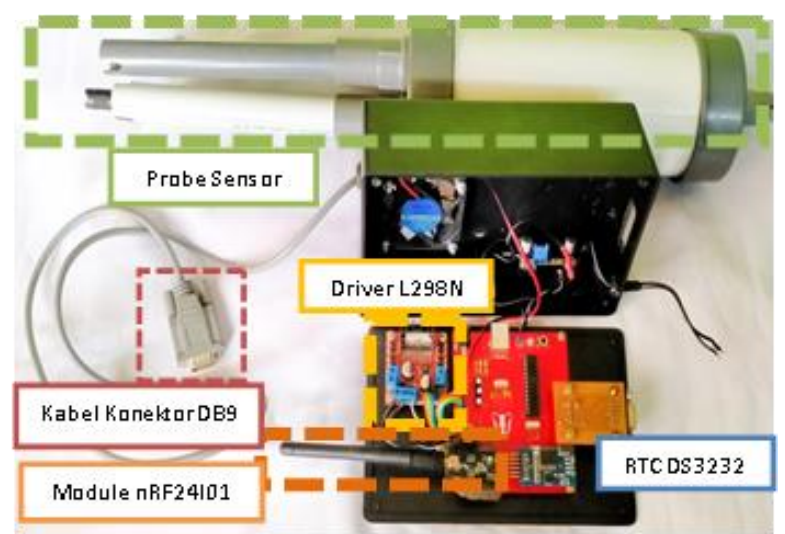

(b)

Gambar 3. Perangkat keras pengirim data (transmitter): (a) Probe sensor dan (b) Blok pengirim (transmitter)

Perangkat keras sensor terdiri dari beberapa komponen yaitu rangkaian sensor DS18B20 yang digunakan untuk mengukur suhu air, sensor pH Meter Kit Dfrobot digunakan untuk mengukur kadar $\mathrm{pH}$ air, sensor salinitas untuk mengukur kadar garam dalam air, dan sensor analog Dissolved Oxygen (DO) untuk mengukur kadar oksigen terlarut dalam air tambak. Bentuk rancangan mekanik perangkat pengirim data dapat dilihat pada Gambar 4.

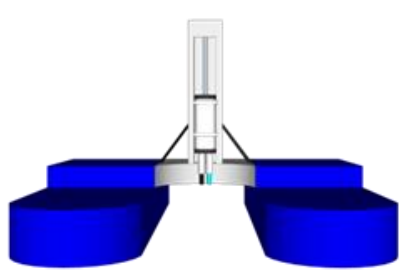

(a)

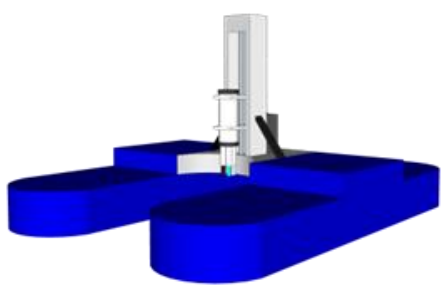

(b)

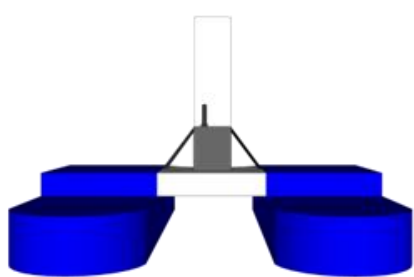

(c) 
Gambar 4. Rancangan mekanik dari perangkat pengirim data (transmitter) (a) Tampak depan, (b) Tampak samping (c) Tampak belakang

Pada sistem ini, perangkat sensor dihubungkan dengan perangkat pengirim data menggunakan kabel penghubung DB9 untuk meringkas pengkabelan pada rangkaian sensor. Perangkat keras pengirim (transmitter) sendiri terdiri dari beberapa komponen diantaranya modul nRF24101+ yang digunakan sebagai media pengiriman data hasil pembacaan sensor ke titik penerima dan modul RTC3231 yang digunakan sebagai pengatur waktu pengambilan data dari sensor sekaligus untuk mengatur waktu kerja motor stepper. Motor stepper ini digunakan untuk memutar batang ulir dengan panjang $0,8 \mathrm{~m}$ pada proses pengambilan data sensor secara otomatis. Sumber tegangan pada perangkat keras pengirim data dan sensor ini menggunakan modul power supply dengan keluaran tegangan 12 Volt DC. Tegangan dari power supply diturunkan menggunakan modul LM2596 adjustable step-down menjadi 8 Volt agar tidak menimbulkan panas pada regulator AMS1117 yang dapat merusak arduino UNO dalam penggunaan jangka waktu lama. Pada penelitian ini berat beban rangkaian sensor digunakan sekitar $2 \mathrm{~kg}$ sehingga torsi motor yang dibutuhkan untuk memutar batang ulir sekitar 0,981 Nm. Jenis motor stepper yang baik digunakan yaitu motor yang memiliki torsi diatas $0,981 \mathrm{Nm}$. Jenis motor stepper yang digunakan pada penelitian ini ialah motor stepper Nema 23 dengan torsi sebesar 1,26 Nm. Kecepatan berputar motor diatur dalam program Arduino yaitu sebesar $60 \mathrm{rpm}$. Sehingga waktu yang dibutuhkan alat untuk menurunkan sensor sebesar 32 detik.

Pada penelitian ini juga dilengkapi dengan sistem perangkat keras penerima (receiver) yang berfungsi untuk menerima dan mengolah data hasil pengukuran yang dikirim oleh perangkat pengirim (transmitter). Hasil realisasi dari sistem perangkat penerima (receiver) ditunjukan pada Gambar 5. Perangkat ini berfungsi sebagai penerima data hasil pembacaan sensor yang dikirimkan dari perangkat pengirim. Sumber tegangan yang digunakan pada sistem ini menggunakan modul power supplay dengan tegangan 24 volt yang diturunkan menggunakan penurun tegangan LM 2596 adjustable step down menjadi 8 volt DC. Melalui perangkat ini, hasil pengukuran dapat dimonitor dengan jarak yang cukup jauh. Hasil pengukuran yang diterima pada penerima ini ditampilkan pada LCD 20x4 karakter. Tampilan LCD pada perangkat receiver dapat dilihat pada Gambar 6.

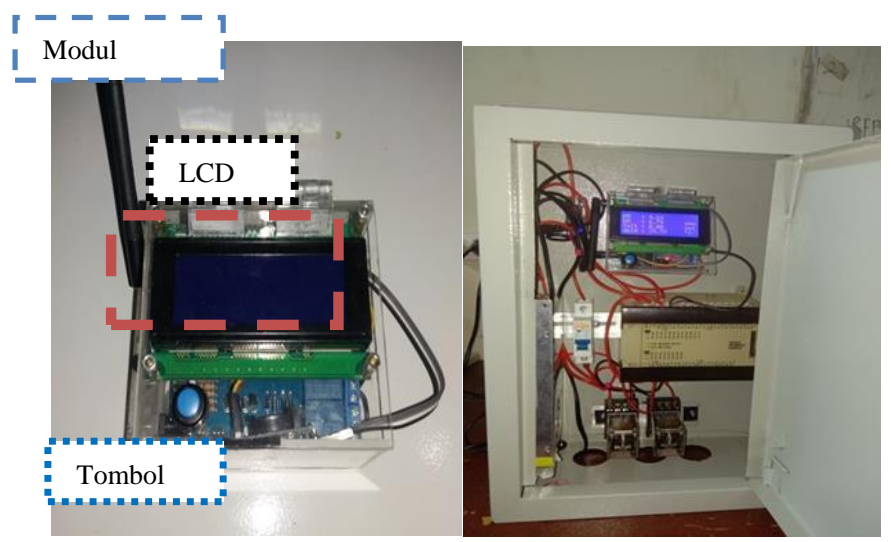

(a)

(b)

Gambar 5. (a) Perangkat keras penerima data (receiver) dan (b) Bagian Keseluruhan.

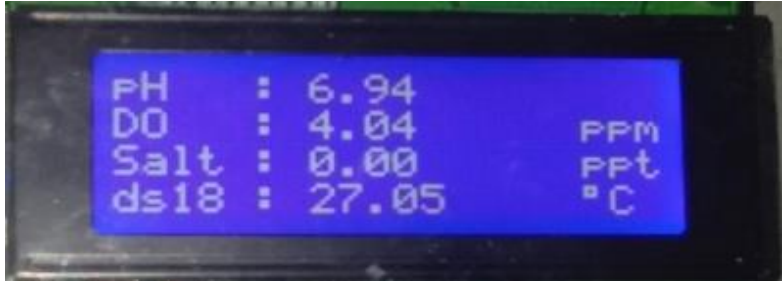

Gambar 6. Tampilan LCD dari perangkat penerima data (receiver).

\subsection{Pengujian Sensor}

\section{Sensor Suhu DS18B20 Waterproof}

Sensor DS18B20 waterproof digunakan untuk mendeteksi nilai temperatur pada perairan. Sensor ini merupakan sensor digital yang memiliki 12 -bit ADC internal dan akurasi sebesar \pm 0.5 derajat pada rentang $-10^{\circ} \mathrm{C}$ sampai dengan $85^{\circ} \mathrm{C}$. Pengujian sensor DS18B20 waterproof dilakukan agar pembacaan sensor sesuai dengan standar pembacaan alat yang terkalibrasi. Pengujian sensor DS18B20 waterproof dilakukan dengan cara membandingkan secara langsung sistem perangkat keras sensor DS18B20 waterproof yang sudah dibuat dengan thermometer tipe HTC-2 yang telah terkalibrasi. Pengambilan data dilakukan dengan mengukur secara langsung temperatur air yang telah dipanaskan dan kemudian didiamkan pada ruang terbuka. Pengukuran dilakukan pada perubahan nilai temperatur air tiap $\pm 1^{\circ} \mathrm{C}$ dari rentang suhu $\pm 49^{\circ} \mathrm{C}$ sampai dengan $\pm 25^{\circ} \mathrm{C}$. Dari nilai rata-rata tiap pengukuran diperoleh hasil perbandingan pengujian sensor DS18B20 waterproof terhadap termometer HTC-2 ditunjukkan pada Gambar 7. 


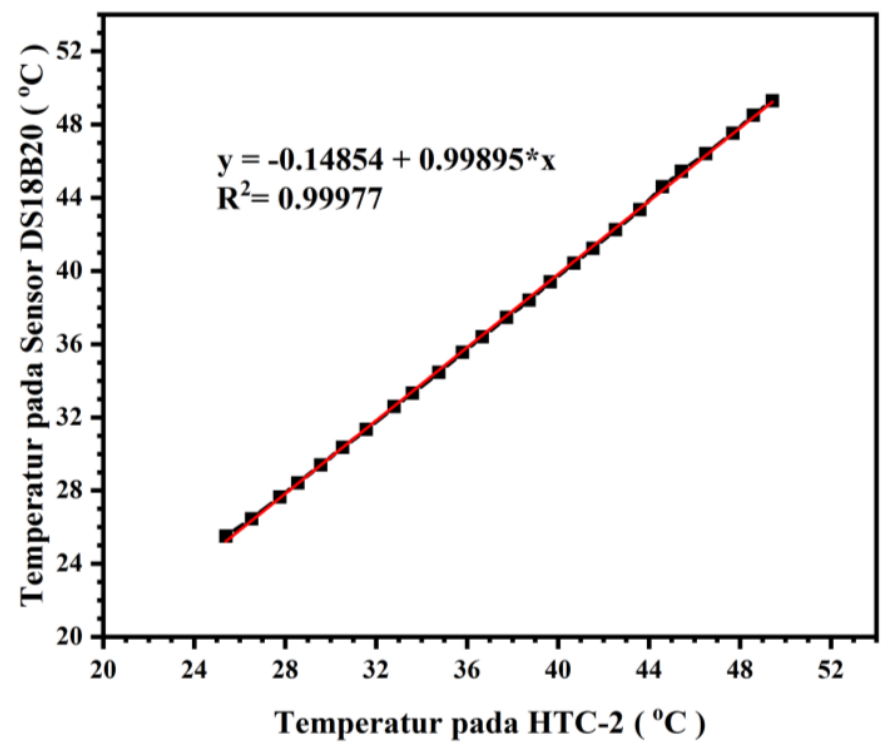

Gambar 7. Grafik hasil pengujian persamaan linieritas temperatur pada sensor DS18B20 waterproof terhadap thermometer tipe HTC-02

Hasil pengujian persamaan linieritas temperatur pada sensor DS18B20 waterproof terhadap thermometer tipe HTC-02 pada Gambar 7 menunjukkan linieritas yang diperoleh lebih baik dari sebelumnya yaitu sebesar $R^{2}=$ 0,99977. Nilai $R^{2}$ merupakan tingkat kesesuaian persamaan garis yang diperoleh terhadap variasi data dengan rentang nilai $0-1$. Jika nilai $R^{2}$ semakin mendekati 1 maka persamaan garis yang diperoleh sesuai dengan variasi data (Effendi, 2019).

Hasil perhitungan diperoleh nilai rata-rata akurasi sebesar 99,42\% dan nilai rata-rata error 0,58. Semakin kecil persentase error yang dihasilkan dan semakin besar persentase akurasi yang dihasilkan maka kinerja alat semakin baik (Halim dkk., 2016). Selain itu, nilai rata-rata tingkat presisi yang diperoleh dari perhitungan yaitu sebesar $99,33 \%$ dan selisih rata-rata setiap pengukuran yang diperoleh sebesar $0,196{ }^{\circ} \mathrm{C}$. Semakin tinggi nilai presisi maka semakin tepat pengukuran tersebut (Jones dan Chin, 1991). Hasil tersebut menunjukkan bahwa sensor DS18B20 waterproof memiliki tingkat akurasi dan presisi yang baik.

\section{Sersor $\mathrm{pH}$ Meter Kit Dfrobot}

Proses pengujian sensor pH Meter Kit Dfrobot dilakukan dengan membandingkan pengukuran pada larutan buffer yang diperoleh dari Laboratorium Kimia FMIPA Universitas Lampung. Larutan buffer adalah larutan yang dapat menjaga (mempertahankan) pH-nya dari penambahan asam, basa, maupun pengenceran oleh air. Sensor diuji dengan melakukan pengukuran pada larutan buffer yang bernilai 3,4,5,6,7,9, dan 10. Pengujian dilakukan sensor pH Meter Kit Dfrobot sebanyak 5 kali pengulangan seperti yang ditunjukan pada Gambar 8.

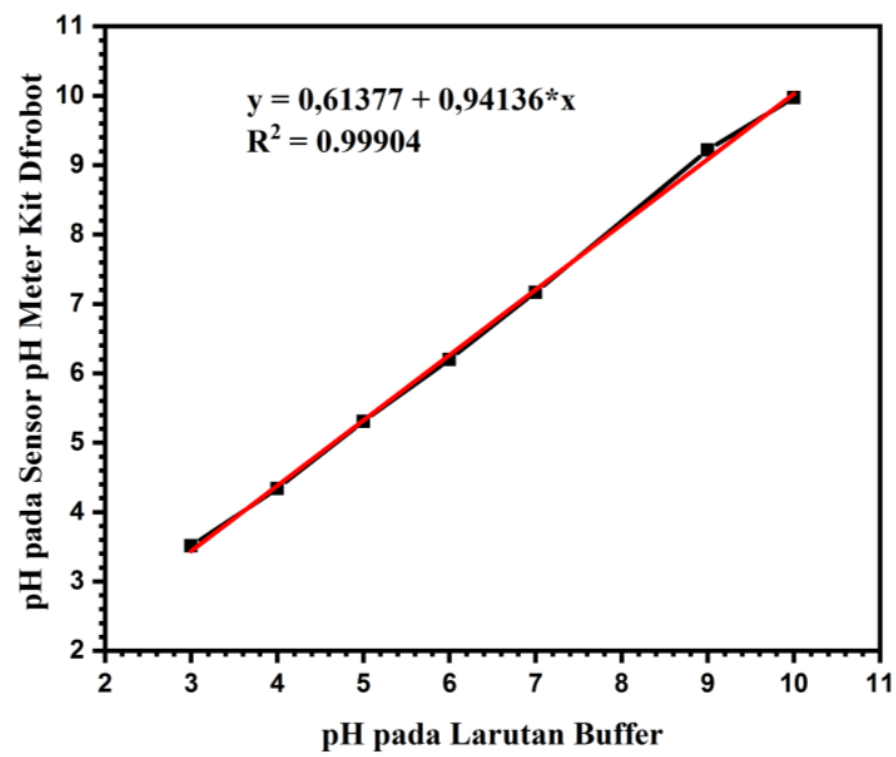

Gambar 8. Grafik pengujian persamaan linieritas sensor pH Kit Meter Dfrobot terhadap larutan buffer 
Hasil pengujian persamaan linieritas sensor pH Meter Kit Dfrobot terhadap larutan Buffer pada Gambar 8 menunjukkan sensor $\mathrm{pH}$ Meter Kit Dfrobot memiliki linieritas yang baik yaitu sebesar $R^{2}=0,99904$. Hasil perhitungan diperoleh rata-rata nilai persen error sebesar 5,74\%. Nilai error tersebut menunjukkan bahwa error dapat ditoleransi karena masih di bawah 10\% (Effendi, 2019). Selain itu, nilai akurasi yang diperoleh dari perhitungan sebesar 94,06 \% dengan rata-rata selisih pengukuran sebesar 0,25. Pada pengujian ini juga dilakukan perhitungan rata-rata presisi sensor pH Meter Kit Dfrobot yaitu dengan nilai sebesar 99,97\%. Tinggi nilai presisi menunjukkan semakin tepat pengukuran tersebut (Jones dan Chin, 1991). Hasil tersebut menunjukkan bahwa Sensor pH Meter Kit Dfrobot memiliki tingkat akurasi dan presisi yang baik

\section{Sensor Salinitas}

Sensor salinitas merupakan salah satu sensor kimia yang dirancang berdasarkan sifat kelistrikan air. Resistansi pada air akan berkurang seiring dengan bertambahnya kadar garam. Sensor salinitas terdiri dari dua buah elektroda yang dicelupkan kedalam air. Pada penelitian ini dilakukan kalibrasi sensor salinitas agar pembacaan sensor sesuai dengan standar pembacaan refractometer. Kalibrasi dilakukan dengan cara membandingkan secara langsung keluaran tegangan ADC pada elektroda dengan salinitas larutan yang dibuat. Sampel larutan dibuat dengan cara melarutkan garam dengan air dan telah diukur dengan refractometer.

Hasil pengujian sensor Salinitas dibandingkan dengan nilai salinitas pada sempel yang telah diukur menggunakan refractometer. Hasil pengujian sensor salinitas terhadap refractometer ditunjukkan pada Gambar 9. Grafik Hasil pengujian sensor salinitas yang telah terkalibrasi pada Gambar 9 menunjukkan linieritas yang diperoleh lebih baik dari yang sebelumnya dengan $R^{2}=0,95609$. Dari hasil perhitungan data pengujian sensor diperoleh rata-rata nilai persen error cukup besar yaitu 21,86\% dengan nilai rata-rata selisih pengukuran sensor sebesar 3,17 sehingga nilai akurasi sensor salinitas yang diperoleh yaitu sebesar $78,14 \%$. Nilai error tersebut melebihi batas toleransi nilai error karena berada diatas 10\% (Effendi, 2019). Selain itu, nilai rata-rata presisi sensor yang diperoleh dari perhitungan sebesar 86,53\%. Pengujian yang dilakukan menunjukkan bahwa sensor salinitas dalam keadaan yang kurang baik untuk mengukur salinitas pada air. Hasil dari pengujian kinerja sensor akan terus menurun setelah digunakan dalam pengukuran yang lama didalam air karena batang anoda pada sensor terlalu cepat mengalami korosi.

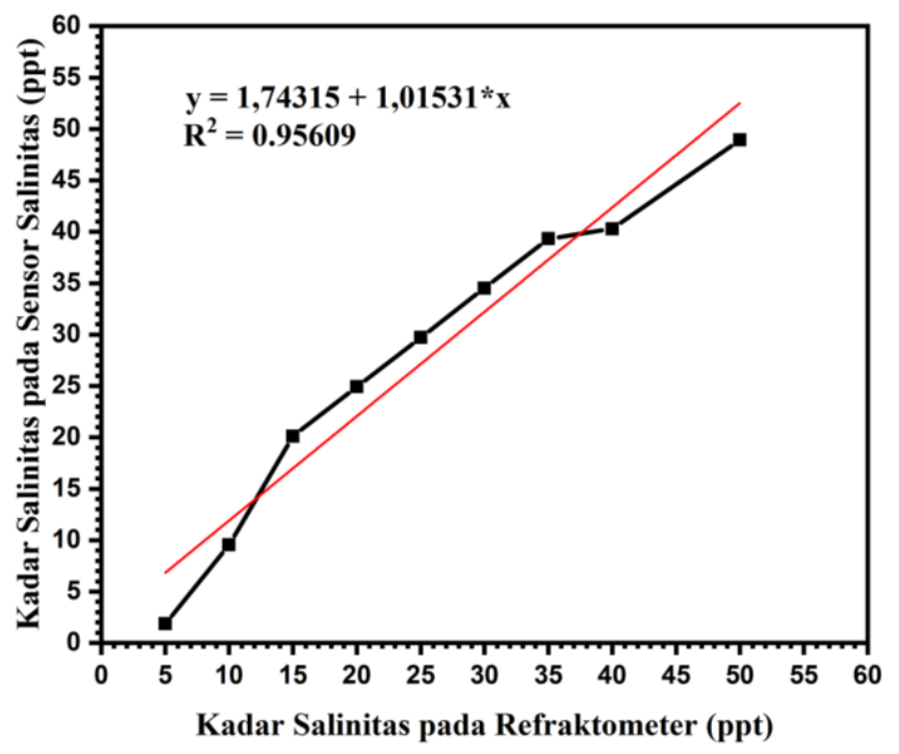

Gambar 9. Grafik pengujian linieritas sensor salinitas dengan nilai salinitas refractometer

\section{Sensor Analog Dissolved Oxygen}

Pengujian sensor dilakukan dengan cara membandingkan perangkat sensor analog DO yang dibuat dengan alat standar sensor DO Meter tipe YSI55.Sensor analog DO mampu mendeteksi range antara 0 sampai $20 \mathrm{mg} / 1$ dengan kecepatan respon 90 detik. Untuk sensor DO Meter YSI55 mampu mengukur oksigen terlarut dari rentang antara 0 sampai $20 \mathrm{mg} / 1$ dengan resolusi terkecil $0.01 \mathrm{mg} / 1$. Sempel yang dipakai pada pengujian sensor analog DO ini terdiri dari 6 sempel yang diambil dari tempat yang berbeda-beda. Pengujian dilakukan dengan membandingkan hasil pengukuran kedua sensor pada keenam sempel yang diperoleh.

Grafik hasil pengujian linieritas yang dilakukan pada sensor analog DO dengan sensor DO Meter tipe YSI55 pada Gambar 10, menunjukkan nilai $R^{2}=0,90267$. Nilai $R^{2}$ merupakan tingkat kesesuaian persamaan garis yang diperoleh terhadap variasi data dengan rentang nilai 0-1. Jika nilai $R^{2}$ semakin mendekati 1 maka persamaan garis yang diperoleh sesuai dengan variasi data (Effendi, 2019). Dari data pengujian sensor analog DO diperoleh ratarata nilai persen kesalahan sebesar 9,4662\%, akurasi sebesar 90,5338\%, dan rata-rata selisih pengukuran kedua sensor sebesar 0,32.

Pengujian yang dilakukan menunjukkan bahwa sensor analog DO kurang baik saat membaca kadar oksigen terlarut dibawah nilai $1 \mathrm{ppm}$, namun masih dapat melakukan pengukuran dengan baik pada rentang 2-5 ppm. Berdasarkan hasil pengujian dapat dikatakan kinerja sensor dalam keadaan baik dan dapat digunakan dalam proses pengukuran kadar oksigen terlarut dalam air. 
Pauzi GA, Suryadi OF, Susanto GN, dan Junaidi, 2020, Rancang Bangun Sistem Monitoring Kualitas Air Tambak Udang (Litopenaeus Vannamei) Menggunakan Wireless Sensor Sistem (WSS) yang Terintegrasi dengan PLC CPM1A, Jurnal of Energy, Material, and Instrumentation Technology, Vol. 1 No. 3, 2020

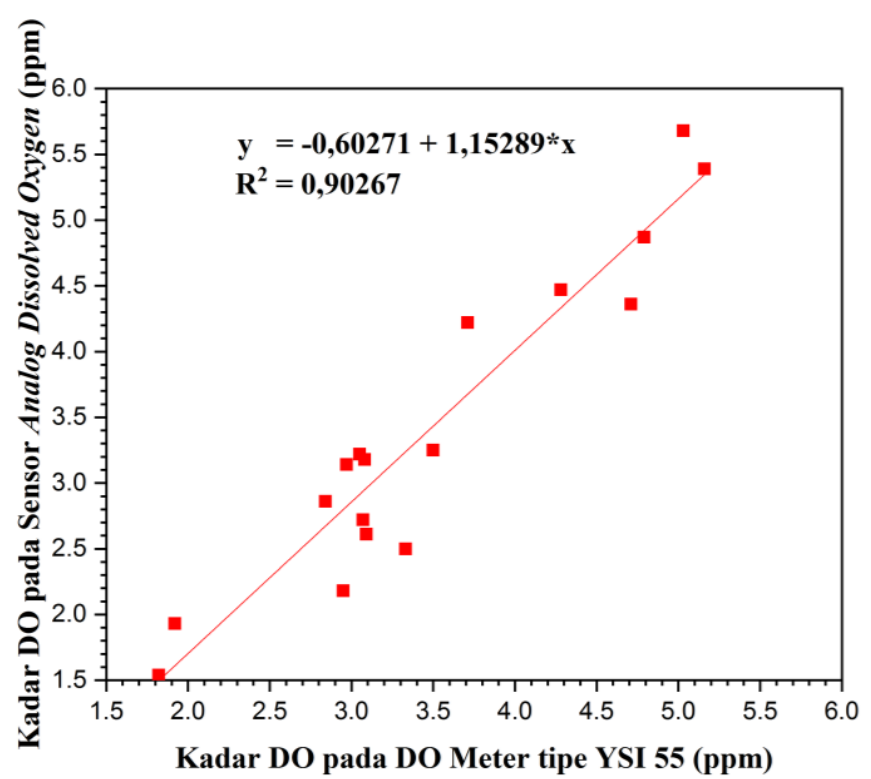

Gambar 10. Grafik pengujian persamaan linieritas sensor analog DO terhadap sensor DO Meter tipe YSI 55

\subsection{Pengujian Mekanik Sistem}

Pengujian sistem mekanik ini dilakukan untuk mengetahui apakah program naik turunnya sensor sudah berjalan baik. Pada penelitian ini program disetting untuk melakukan 4 kali pengambilan data yaitu pagi, siang, sore dan malam hari. Program disetting menurunkan sensor pagi hari pukul $06.00 \mathrm{WIB}$, siang 12.00 WIB, sore 17.00 WIB dan malam hari pukul 23.00 WIB. Contoh program untuk menurunan sensor salah satunya ialah if $((\mathrm{jam}==6) \& \&($ menit $==0) \& \&($ detik $==0))$ myStepper.step(kanan) yaitu jika RTC DS3231 sudah membaca jam 6 menit ke 0 dan detik ke 0 maka motor stepper akan diperintahkan bergerak ke kanan menurunkan sensor. Berikut contoh kondisi sensor saat sudah diturunkan dan melakukan pengambilan data dapat dilihat pada Gambar 11. Motor stepper disetting dengan kecepata $60 \mathrm{rpm}$ dengan jarak awal sensor sampai ke titik pengukuran 0,5 m, maka waktu yang dibutuhkan untuk menurunkan sensor ke titik pengukuran ialah 19,9 detik. Lamanya sensor direndam didalam air disetting pada program selama 1 jam pembacaan dan data dikirim pada menit ke 30 saat pembacaan sensor. Setelah melakukan pembacaan sensor selama 1 jam maka sensor akan diangkat dengan menggunakan listing program pada Arduino. Contoh program yang digunakan ialah if $((j a m==7)$ $\& \&($ menit $==0) \& \&($ detik $==0)$ ) myStepper.step(kiri) dimana jika pembacaan waktu pada RTC sudah pukul 7 menit 0 dan detik ke 0 maka motor stepper akan bergerak ke kiri mengangkat sensor.

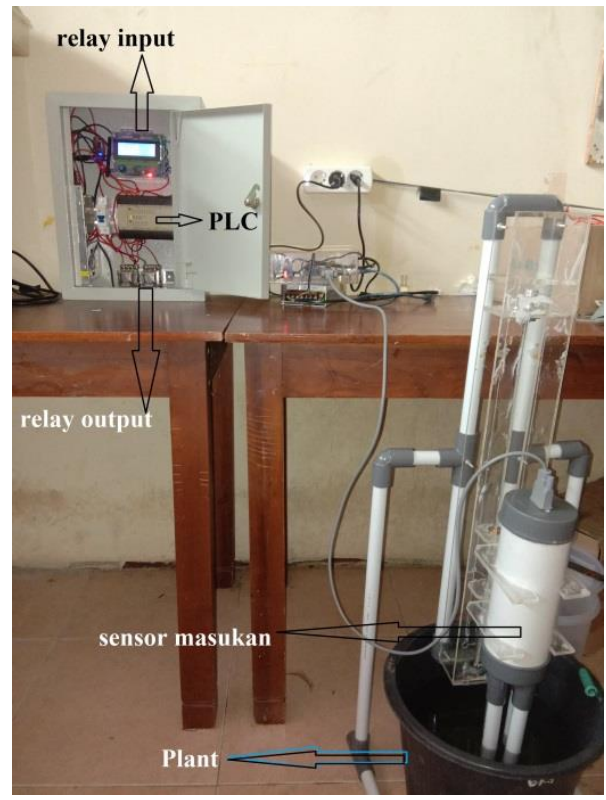


Gambar 11. Kondisi sensor saat sudah diturunkan dan melakukan pengambilan data

\subsection{Pengujian Sistem Komunikasi Data}

Sistem ini dapat melakukan monitoring kualitas air secara otomatis. Hasil dari pemantauan pada perangkat transmitter dikirimkan secara telemetri menggunakan modul nRF24101. Kemudian data yang diterima oleh perangkat receiver ditampilkan di LCD $20 \times 4$.

Untuk mengetahui sistem komunikasi data telah berjalan dengan baik maka dilakukan pengujian sistem dengan mengamati keempat parameter serta pengiriman data dari perangkat pengirim ke penerima. Pengujian alat dilakukan selama 3 hari dengan pengambilan data monitoring sebanyak 3 kali yaitu pagi, siang, dan sore hari. Hasil pengambilan data pada proses pengujian keseluruhan alat dapat dilihat pada Tabel 1.

Berdasarkan data monitoring yang diperoleh saat pengujian keseluruhan sistem yang diperlihatkan pada Tabel 1, bahwa sistem alat sudah bekerja sesuai dengan program yang telah dibuat. Sistem pembacaan sensor dan pengiriman menggunakan modul radio frekuensi nRF24101+ sudah bekerja dengan baik sehingga mampu digunakan untuk proses monitoring.

Tabel 1. Hasil monitoring pada pengujian keseluruhan alat

\begin{tabular}{cccccc}
\hline \multirow{2}{*}{ Hari } & \multirow{2}{*}{ Waktu Pengukuran (WIB) } & \multicolumn{4}{c}{ Nilai Sensor } \\
\cline { 3 - 6 } & & DO $(\mathrm{ppm})$ & Salinitas $(\mathrm{ppt})$ & $\mathrm{PH}$ & Suhu $\left({ }^{\circ} \mathrm{C}\right)$ \\
\hline Pertama & 07.30 & 4.86 & 21 & 7.01 & 27.18 \\
& 12.30 & 3.89 & 21 & 7.20 & 27.18 \\
& 15.30 & 3.36 & 21 & 7.99 & 27.11 \\
\hline Kedua & 07.30 & 3.47 & 21 & 8.19 & 27.11 \\
& 12.30 & 3.39 & 21 & 6.90 & 27.05 \\
Ketiga & 15.30 & 3.86 & 21 & 7.18 & 27.36 \\
& 07.30 & 5.32 & 21 & 6.98 & 27.18 \\
& 12.30 & 4.04 & 21 & 6.94 & 27.05 \\
\end{tabular}

\subsection{Pengujian Kontrol Relay dengan PLC CPM1A}

Pengujian kontrol relay dengan PLC CPM1A dilakukan untuk mengetahui bahwa relay sudah bekerja sesuai dengan nilai parameter kualitas air yang telah dikontrol menggunakan perangkat Arduino UNO. Relay digunakan untuk mengatur tegangan yang menjadi input nilai pada PLC. Tegangan $24 \mathrm{~V}$ yang menjadi input untuk PLC diatur menggunakan relay dengan cara memutus dan menyambung tegangan. Pada sistem ini terdapat dua buah inputan yang digunakan untuk menghidupkan actuator berupa kincir air dan pompa. Skema rangkaian sistem ke PLC CPM1A dapat dilihat pada Gambar 12.

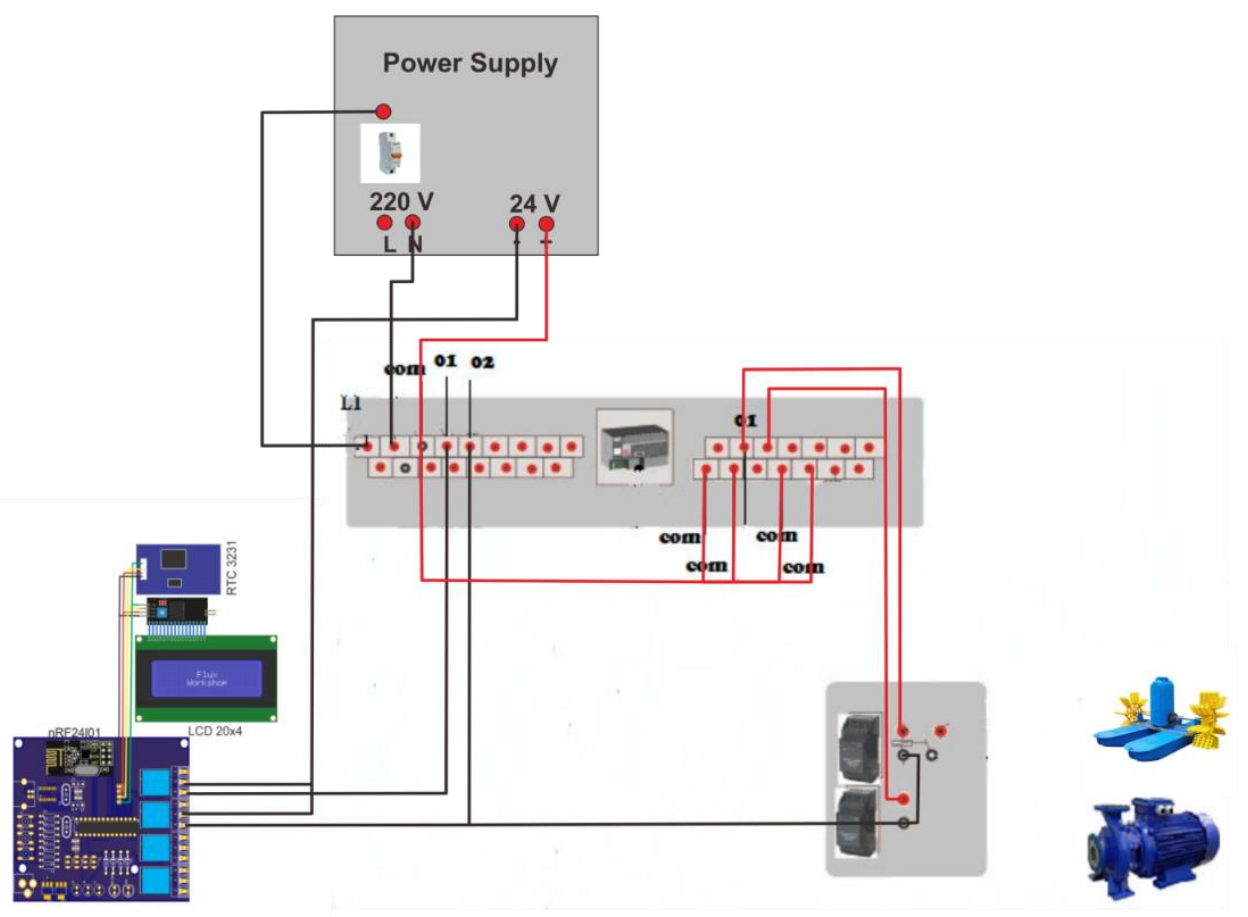

Gambar 12. Skema Wiring Sistem Receiver ke PLC CPM1A 
Pauzi GA, Suryadi OF, Susanto GN, dan Junaidi, 2020, Rancang Bangun Sistem Monitoring Kualitas Air Tambak Udang (Litopenaeus Vannamel) Menggunakan Wireless Sensor Sistem (WSS) yang Terintegrasi dengan PLC CPM1A, Jurnal of Energy, Material, and Instrumentation Technology, Vol. 1 No. 3, 2020

\section{Kesimpulan}

Berdasarkan hasil penelitian, analisis dan pembahasan diperoleh bahwa Sistem monitoring $\mathrm{pH}$, Salinitas, DO, dan Suhu telah direalisasikan dan dapat bekerja dengan baik, modul radio frekuensi nRF24101+ pada perangkat pengirim telah berhasil mengirimkan data dan dikomunikasikan ke perangkat penerima dan jarak pengiriman terjauh pada pengujian dengan adanya penghalang (non line of sigh) diperoleh sejauh 163 meter.

\section{Daftar Pustaka}

Arsad, S., Ahmad, A., Atika, P. P., Betrina M., Dhira K. S., dan Nanik R. B. 2017. Studi Kegiatan Budidaya Pembesaran Udang Vaname (Litopenaeus Vannamei) Dengan Penerapan Sistem Pemeliharaan Berbeda. Jurnal Imiah Perikanan dan Kelautan. Vol. 9 No.1.

Effendi, Khoirul. 2019. Rancang Bangun Sistem Catu Daya dengan Metode Switching Mode Power Supply (SMPS) Berbasis Arduino untuk Aplikasi Elektrospinner. Skripsi. Universitas Lampung. Lampung.

Fuady, M. F., Mustofa N. S dan Haeruddin. 2013. Pengaruh Pengelolaan Kualitas Air Terhadap Tingkat Kelulushidupandan Laju Pertumbuhan Udang Vaname (Litopenaeus Vannamei) di PT. Indokor Bangun Desa, Yogyakarta. Diponegoro Journal of Maquares. Vol. 2. No. 4. pp. 155-162.

Halim, F.R., Suwandi dan Suhendi, A. 2016. Rancang Bangun Syringe Pump menggunakan Motor Stepper Berbasis Arduino. e-Proceeding of Engineering. Vol. 3. No. 2. pp. 2078-2085.

Hudi, L., dan Shahab, A. 2005. Optimasi Produktifitas Udang Vaname (Litopenaeus Vannamei) dengan menggunakan metode Respon Surface dan Non Linier Programming. Skripsi. Institute tekhnologi sepuluh November. Surabaya.

Jones, Larry D. dan A. Foster Chin. 1991. Electronics Instruments and Measurements. Upper Saddle River: PrenticeHall.

Komarawidjaja, W. 2006. Pengaruh Perbedaan Dosis Oksigen Terlarut (DO) Pada Degradasi Amonium Kolam Kajian Budidaya Udang. Jurnal Hidrosfir. Vol 1. No 1. pp. 32-37.

Lintang, E., Firdaus, dan Nurcahyani, I. 2017. Sistem Monitoring Kualitas Air pada Kolam Ikan Berbasis Wireless Sensor Network Menggunakan Komunikasi Zigbee. Prosiding SNATIF. ISBN: 978-602-1180-50-1. pp. 145152.

Machzar, A. F., Akbar, S. R., \& Fitriah, H. 2018. Implementasi Sistem Monitoring Kualitas Air Pada Budidaya Tambak Udang dan Bandeng. Jurnal Pengembangan Teknologi Informasi dan Ilmu Komputer. Vol. 2. No.10. pp. 3458-3465.

Pratama, A. 2017. Studi Performa Udang Vaname (Litopenaeus Vannamei Boone, 1931) Yang Dipelihara Pada Kondisi Air Tambak Dengan Kelimpahan Plankton Yang Berbeda Pada Saat Penebaran. Skripsi. Universitas Lampung. Bandar Lampung. 